\title{
The impact of economic policy uncertainty on PM2.5 pollution-evidence from 25 countries
}

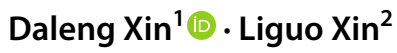

Received: 22 June 2021 / Accepted: 6 January 2022 / Published online: 24 January 2022

( $)$ The Author(s), under exclusive licence to Springer-Verlag GmbH Germany, part of Springer Nature 2022

\begin{abstract}
We conduct theoretical and empirical study on the impact of economic policy uncertainty on PM2.5 pollution. Economic policy uncertainty has important impact on PM2.5 pollution through investment channel and innovation channel. Specifically, according to real option theory, increase in economic policy uncertainty can reduce investment, thereby reducing PM2.5 pollution. However, increase in economic policy uncertainty can hinder corporate's innovation activities, which in turn make PM2.5 pollution increase. Therefore, the impact of economic policy uncertainty on PM2.5 pollution depends on the combination effect of these two different effects. Furthermore, using 25 countries' unbalanced panel data and fixed effects estimation methods, we empirically test the impact of economic policy uncertainty on PM2.5 pollution. The results show that, with the increase of economic policy uncertainty, countries' PM2.5 pollution has significantly decreased. In addition, economic policy uncertainty has heterogeneous effect on countries' PM2.5 pollution. Compared with countries who have higher R\&D input, increase in economic policy uncertainty makes the reduction of PM2.5 pollution in countries with relatively lower R\&D input higher. By changing the measurement methods of economic policy uncertainty and PM2.5 pollution indicators, and using 2SLS methods to estimate the models, the conclusions of the paper are robust. Finally, we put forward corresponding policy implications.
\end{abstract}

Keywords Economic policy uncertainty $\cdot$ PM2.5 pollution $\cdot$ Investment $\cdot$ Innovation $\cdot$ Heterogeneous effect

\section{Introduction}

Since global financial crisis in 2008, the world economy begins to recover slowly, and people's living standards have gradually improved. However, in recent years, economic counter-globalization trends, Brexit, coronavirus (COVID19) pandemic, and Sino-US economic and trade frictions have made the current global economic development facing many challenges. In order to promote economic growth, many countries' governments have implemented

Responsible Editor: Eyup Dogan

Daleng Xin

xindaleng@163.com

Liguo Xin

xlg@sdu.edu.cn

1 School of Economics, Shandong Normal University, No.1 University Road, Changqing District, Jinan 250358, China

2 School of Management, Shandong University, No.27 Shanda Nanlu, Licheng District, Jinan 250100, China a series of economic stimulus policies. The implementation of these economic policies, on the one hand, can make domestic economy out of recession as soon as possible and promote economic development. On the other hand, frequently implemented economic policies have also increased the uncertainty of economic policies faced by the economies, which are not conducive to the development of the real economy. Indeed, increase in economic policy uncertainty has important impact on economic development, and many economists have analyzed these effects. For example, economists have analyzed the impact of economic policy uncertainty on corporate investment, innovation behavior, economic growth, financial stability, employment, and have obtained rich research conclusions. Furthermore, economic policy uncertainty could influence regional environmental pollution. Environmental pollution is still an important challenge faced by countries in the world today. For example, air pollution is one of the focuses of attention in recent years, especially PM2.5 pollution. PM2.5 air pollution has an important impact on people's physical and mental health, as well as medical 
Fig. 1 World PM2.5 air pollution. Data resource: World bank WDI database

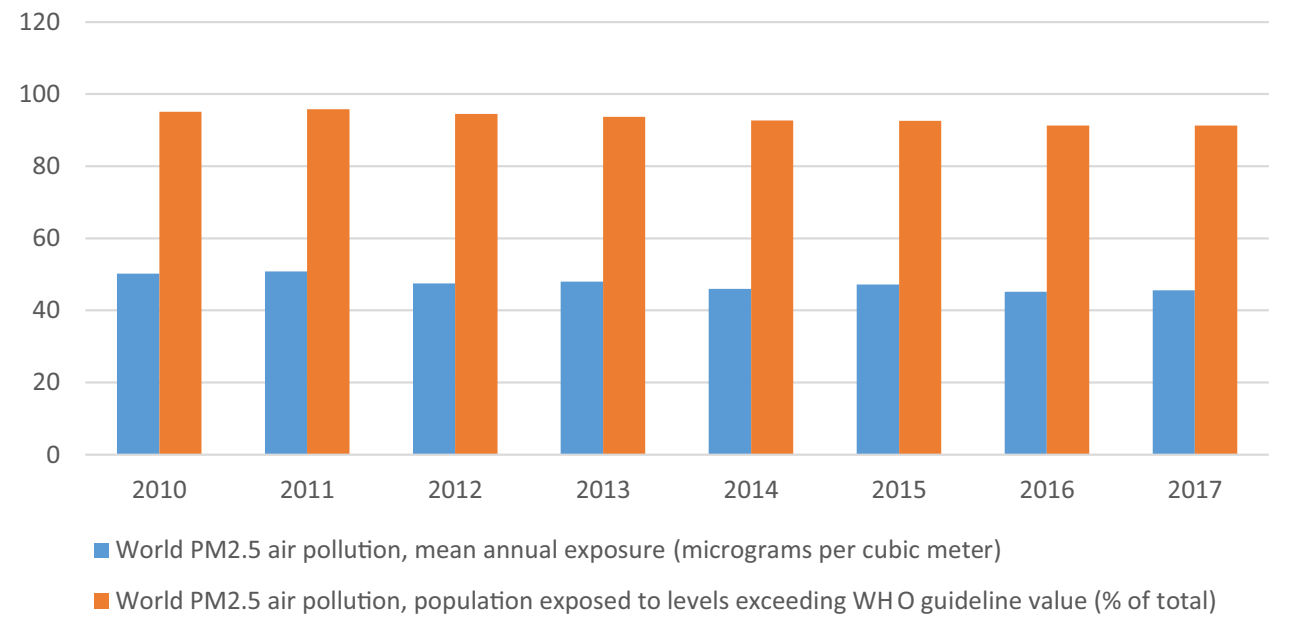

expenditure and economic development (Yang \& Zhang, 2018; Pangaribuan et al., 2019; Signoretta et al., 2019; Dong et al., 2020; Guan et al., 2021b). Among the many air pollutants, PM2.5 pollution has become the main pollutant in recent years, especially in developing countries, such as China (Xu \& Lin, 2018; Wu et al., 2020). And it has attracted the attention of many economists. PM2.5 pollutants are small, highly active, and easy to carry toxic and harmful substances and have a long residence time in the atmosphere and a long transportation distance. Thus, PM2.5 pollution has become the fifth leading cause of death, which caused 4.2 million deaths and 103.1 million disability-adjusted life years in 2015 (Cohen et al., 2017; Liu et al., 2019; Zhang et al., 2021). Therefore, it has a greater impact on human health and atmospheric environmental quality. Figure 1 has shown that, currently, nearly $91 \%$ population in the world has exposed to the levels of PM2.5 air pollution which are exceeding WHO guideline value. Donkelaar et al. (2014) argue that the PM2.5 concentrations above the WHO guide-line level have increased from $22 \%$ in $1998-2000$ to $30 \%$ in $2010-2012$. And it is an important leading risk factor for premature mortality (Lim et al., 2012).

PM2.5 pollution is closely related to economic development, and economic policy uncertainty has important impact on economic development. Therefore, what impact will economic policy uncertainty have on PM2.5 pollution and what is the impact mechanism? Economists have not answered these questions. In addition, scholars have argued that increase in economic policy uncertainty will reduce corporate innovation (Xu, 2020), so will the impact of economic policy uncertainty on PM2.5 pollution be different due to country's innovation behavior? Currently, economists have not conducted in-depth research on the above issues. In view of this, based on the unbalanced panel data of 25 countries and using fixed effects estimation methods, we deeply study the relationship between economic policy uncertainty and
PM2.5 pollution from theoretical mechanisms and empirical tests. The study not only expands the economic policy uncertainty theory and environmental pollution theory, but also has important implications for the government's environmental polices.

Compared with previous studies, the main contribution of this paper is as following: Firstly, we analyze the determinants of PM2.5 pollution from a new view, which is economic policy uncertainty. Many scholars test the effect of socioeconomic factors or urbanization on the PM2.5 pollution, but they do not explore the effect of economic policy uncertainty on PM2.5 pollution. According to real option theory and corporate innovation theory, this paper explores the impact mechanism of economic policy uncertainty on PM2.5 pollution. Secondly, based on 25 countries' unbalanced panel data, this paper empirically tests the impact of economic policy uncertainty on PM2.5 pollution. Moreover, by dividing different samples, we also empirically test the heterogeneous effect of economic policy uncertainty on PM2.5 pollution in different countries, so we get more interesting results. Finally, in order to increase the robustness of the empirical results, we conduct robustness checks by changing the measurement methods of the economic policy uncertainty and PM2.5 pollution indicators, and using 2SLS methods to estimate the econometric models. In short, this paper not only reveals the relationship between economic policy uncertainty and PM2.5 pollution, but also provides some policy implications for reducing environmental pollution and promoting sustainable economic development.

The remaining structure of this paper is as following: The second part is literature review. The third part we explain the impact mechanism of economic policy uncertainty on PM2.5 pollution. The fourth part introduces the empirical strategy. The fifth part introduces the empirical results. Finally, we give the conclusions and policy implications. 


\section{Literature review}

The impact of economic policy uncertainty on economic development and environmental pollution has always been the key issues of academic research (Bloom, 2007; Baker et al., 2012, 2016; Pirgaip \& Dinçergök, 2020). Economists have found that increase in uncertainty inhibits corporate investment (Bloom et al., 2007; Julio \& Yook, 2012; Stein \& Stone, 2013; Dejuán \& Ghire1li, 2018; Liu \& Zhang, 2019). According to the theory of real option, the increase in uncertainty makes firm reduce current investment and increase future investment to obtain higher value, so firm will reduce current investment activities (Bernanke, 1983; McDonald \& Siegel, 1986; Pindyck, 1990; Pindyck \& Solimano, 1993; Leahy \& Whited, 1996; Guiso \& Parigi, 1999; Bulan, 2005). As a form of uncertainties, economists have justified that economic policy uncertainty has a large negative impact on corporate investment. For example, Wang et al. (2014) use data from Chinese listed companies to empirically test the impact of economic policy uncertainty on corporate investment. They find that increase in economic policy uncertainty reduces corporate investment. However, if the firm has a higher rate of return on investment capital, uses more internal financing or the firm is a non-state-owned enterprise, then the negative impact of economic policy uncertainty on corporate investment can be reduced. Kang et al. (2014) also find that the increase in economic policy uncertainty significantly inhibits corporate investment. This negative impact is greater for firms with higher economic policy uncertainty and during periods of economic recession. Gulen and Ion (2015) analyze the impact of policy uncertainty on corporate investment behavior based on the theory of real option and the irreversibility of investment. They find that the increase in policy uncertainty inhibits corporate capital investment. Moreover, this inhibitory effect is stronger for firms with relatively high degree of irreversibility of investment and relatively high dependence on government expenditures. Jens (2017) maintains that increase in political uncertainty reduces corporate investment. An empirical study by Drobetz et al. (2018) using the economic policy uncertainty index constructed by Baker et al. (2016) and firm-level data from 21 countries also finds that increase in economic policy uncertainty reduces corporate investment. They argue that economic policy uncertainty distorts the relationship between investment and capital cost. Liu and Zhang (2019) using data from China's listed companies also find that increasing economic policy uncertainty hinders corporate investment, but economic policy uncertainty has no impact on state-owned enterprises. Akron et al. (2020) conduct an empirical study using data from US hospital industry companies and find that the increase in economic policy uncertainty reduces hospitality company's investment. In addition, economic policy uncertainty also has an important impact on enterprises' R\&D investment or innovation behavior. For example, Stein and Stone (2013) argue that uncertainty encourages the R\&D spending of enterprises. Atanassov et al. (2015) regard US gubernatorial elections as an exogenous source of government policy uncertainty and empirically test the impact of political uncertainty on corporate $\mathrm{R} \& \mathrm{D}$ investment. They find that rising political uncertainty has increased corporate R\&D investment, and this impact is even stronger in fiercely competitive elections regions, in industries that are politically sensitive and difficult to innovate, and in companies with higher growth value and greater product market competition. However, some economists have found that the increase in economic policy uncertainty inhibits corporate R\&D or innovation. For example, $\mathrm{Xu}$ (2020) argues that the increase in uncertainty of government economic policies increases the cost of capital of enterprises, which in turn reduces enterprise innovation. Companies with more severe credit constraints and companies that rely more on external finance suffer more negative effects. Finally, some economists have found that increase in economic policy uncertainty leads to a decline in employment (Leduc \& Liu, 2012; Mulligan, 2014; Nodari, 2014; Baker et al., 2016), and increase in corporate cash holdings (Demir \& Ersan, 2017), reduce financial stability (Phan et al., 2020), reduce trade credit (D'Mello \& Toscano, 2020), and is not conducive to economic growth (Nilavongse et al., 2020). Overall, most scholars have justified that increase in economic policy uncertainty can significantly reduce corporate investment and innovation. From another point of view, corporate investment behavior and innovation behavior could influence regional PM2.5 pollution (Cheng et al., 2020; Yan et al., 2021). Therefore, economic policy uncertainty may influence PM2.5 pollution through investment and innovation channel.

In addition, there are few research about the effect of economic policy uncertainty on PM2.5 pollution. But some economists have analyzed the impact of economic policy uncertainty on environmental pollution, carbon emissions (Jiang et al., 2019), and renewable energy investment. Romano and Fumagalli (2018) point out that policy uncertainty has an important impact on the low-carbon technology investment behavior of the economy. Jiang et al. (2019) argue that economic policy uncertainty will affect the business environment of economic entities, which in turn affects the economic entities' decision-making, such as carbon emissions. They use US industry-level data from January 1985 to August 2017 to empirically test the linear and non-linear granger causality between economic policy uncertainty and carbon emissions. Their results show that, 
overall, there is no causality between the uncertainty of US economic policy and the median quantile carbon emission growth. However, in terms of the growth of carbon emission in the upper and lower quantile, the impact of the US economic policy uncertainty on carbon emissions has granger causality. From an industry perspective, residential sector, electric power sector, and transportation sector, the impact of economic policy uncertainty on the carbon emissions of these industries and the overall impact are consistent. However, economic policy uncertainty has no significant impact on the carbon emissions of the commercial sector. Furthermore, Jiang et al. (2019) argue that economic policy uncertainty affects a country's carbon emissions by affecting the macroeconomic situation and household consumption decisions. Pirgaip and Dinçergök (2020) get similar results with Jiang et al. (2019). They use data from G7 countries to analyze the granger causal relationship between economic policy uncertainty, energy consumption, and carbon emissions. They find that economic policy uncertainty has a significant unidirectional causal relationship to Japan's energy consumption. Economic policy uncertainty has a significant unidirectional causal relationship to carbon emissions in the USA and Germany. Economic policy uncertainty has a significant unidirectional causal relationship both in energy consumption and $\mathrm{CO} 2$ emissions in Canada. However, there is a bidirectional causality between economic policy uncertainty and energy consumption in Italy. Different from the above research, Adedoyin and Zakari (2020) get different point of view. They analyze the impact of economic policy uncertainty on carbon emissions using the UK's annual data from 1985 to 2017. Their empirical results find that economic policy uncertainty reduces Britain's carbon emissions in the short term. But in the long run, the increase in economic policy uncertainty will increase carbon emissions. Amin and Dogan (2021) also maintain that increase in economic policy uncertainty causes carbon emissions increasing in China. Wen and Zhang (2022) argue that in China, economic policy uncertainty will harm the environment and increase industrial pollution. Because economic policy uncertainty can encourage local authorities to reduce environmental supervision. Yu et al. (2021) construct provincial economic policy uncertainty index and test the effect of economic policy uncertainty on firm carbon emissions. They find that economic policy uncertainty has significantly positive impact on firms' carbon emission intensity. In addition, Liu et al. (2020) use panel data from 52 Chinese traditional energy companies and 116 renewable energy companies to analyze the impact of economic policy uncertainty on the investment behavior of different types of companies. Their results show that the increase in economic policy uncertainty hinders the investment behavior of coal and petroleum companies. On the contrary, the increase of economic policy uncertainty has promoted the investment behavior of solar energy, geothermal energy and other renewable energy companies.

Finally, many scholars have analyzed the determinants of PM2.5 pollution. For example, Wang et al. (2018) find that democracy, political globalization, and urbanization have important impact on the PM2.5 concentration level of G20 countries. Dong et al. (2018) have verified that there is an environmental Kuznets curve relationship between PM2.5 pollution and per capita GDP in the long run. Ji et al. (2018) argue that income, urbanization level, and service industry development have important effects on PM2.5 pollution. Jiang et al. (2018) find that compared with other sectors, industrial activities cause more PM2.5 pollution. City size and residents' activities will also have important impact on PM2.5 pollution. Cao et al. (2019) show that there is a U-shaped relationship between a prefecture's party secretary's years in office and its average annual PM2.5 level. In addition, there are many studies that analyze the influencing factors of PM2.5 pollution from the perspective of urbanization. For example, the research results of Wang et al. (2019) show that urbanization has a significant effect on PM2.5 concentration, but the degree of its impact varies among groups of countries with different development levels. Dong et al. (2020) using panel data from 216 countries from 1990 to 2016 show that the relationship between urbanization and PM2.5 pollution density are in an inverted U-shaped curve. That is, urbanization will initially increase the density of PM2.5 pollution. However, urban agglomeration effect and technological progress will reduce PM2.5 density in the late stage of urbanization. Zou and Shi (2020) using the Bayesian hierarchical spatial quantile regression model also find that total population, urbanization rate, industrialization level, and energy efficiency have important effects on the level of PM2.5 pollution concentration. Finally, some economists analyze the determinants of PM2.5 pollution based on environmental regulations and government policy perspectives. For example, Zhang et al. (2020) using the spatial panel model show that environmental regulations and industrial structure rationalization have significantly reduced PM2.5 pollution. Xie et al. (2020) also find that China's central heating policy effectively reduces PM2.5 concentration.

In summary, existing studies have conducted in-depth discussions and analyses on the impact of economic policy uncertainty on carbon emissions, green investment, and economic development. However, there are few studies on the impact of economic policy uncertainty on PM2.5 pollution. And the relevant impact mechanisms have not been analyzed. Moreover, current studies select single country or $\mathrm{G} 7$ countries sample to analyze the impact of economic policy uncertainty on environmental pollution or $\mathrm{CO} 2$ 
emissions, and the sample size is relatively small. In view of this, in this paper we will use the unbalanced panel data of 25 countries from 1976 to 2018 as the research sample to conduct theoretical and empirical research on the impact of economic policy uncertainty on PM2.5 pollution. This study has important implications for reducing environmental pollution.

\section{Theoretical mechanism and hypothesis development}

Economic policy uncertainty has an important impact on economic development (Ahsan et al., 2021), and economic development will influence PM2.5 pollution (Luo et al., 2021). Therefore, the economic policy uncertainty could affect PM2.5 pollution through the channel of economic development. Specifically, the increase of economic policy uncertainty hinders enterprise investment and employment (Ghosal \& Ye, 2015; Liu \& Zhang, 2019), so it is not conducive to economic development. On the one hand, increase in economic policy uncertainty makes companies more cautious about the cost of future government regulation and tax policy changes, and their investment behavior will become more cautious (Kang et al., 2014). In addition, according to the real option theory, the increase in economic policy uncertainty makes the value of enterprises waiting for investment and increasing future investment greater, thus inhibiting the current investment behavior of enterprises (Gulen and Ion, 2015). The decline in firm's investment means a decline in economic output, which in turn will reduce PM2.5 pollution. Increase economic output may generate more pollutant emissions and worsen environmental quality ( $\mathrm{Ji}$ et al., 2018). Thus, decline in economic output could reduce PM2.5 pollution. On the other hand, increase in economic policy uncertainty may lead to an increase in investment in renewable energy (Liu et al., 2020). Corporate investment, including foreign direct investment, has an important impact on environmental pollution (Xin \& Zhang, 2020). Therefore, increase in investment in renewable energy will further lead to a decrease in PM2.5 pollution.

However, increase in economic policy uncertainty could inhibit the innovative behavior of enterprises, which will increase PM2.5 pollution. Atanassov et al. (2015) conduct an empirical study by considering the state elections in the USA as an exogenous source of government policy uncertainty. They find that the increase in political uncertainty has led to an increase in corporate $\mathrm{R} \& \mathrm{D}$ investment. That is, compared with non-election years, the company increased $\mathrm{R} \& \mathrm{D}$ investment by $4.6 \%$ on average in election years. However, Jiang et al. (2020) find that the more stable the local policy environment, the more stable the innovation subsidies for enterprises, which promote the number of patent applications by enterprises. Conversely, if the policy environment is unstable, the innovation subsidies of enterprises will be affected, which is not conducive to the innovation of enterprises. Xu (2020) also finds that the increase in economic policy uncertainty has led to a decline in both innovation input and innovation output. Because the increase in economic policy uncertainty makes the cost of capital for enterprises increase, which in turn reduces their innovation activities. Cui et al. (2021), Guan et al. (2021a), and Lou et al. (2022) also confirm that economic policy uncertainty is significantly negatively related with corporate innovation. In short, the increase of economic policy uncertainty restrains the innovation behavior of enterprises. Furthermore, the decline of enterprise innovation behavior is not conducive to the improvement of green production efficiency, thus worsening environmental quality (Chien et al., 2021; Yan et al., 2021). Therefore, through the innovation channel, economic policy uncertainty will increase the country's PM2.5 pollution.

Overall, the impact of economic policy uncertainty on PM2.5 pollution may have positive effect and negative effect, which ultimately depend on the combination effect of the two effects. Therefore, we propose the following two research hypotheses:

Hypothesis 1a: The increase in economic policy uncertainty reduces corporate investment and increases investment in renewable energy, thereby reducing PM2.5 pollution. However, the increase of economic policy uncertainty will also hinder the innovative behavior of enterprises, which will increase the PM2.5 pollution. Overall, the negative effect of economic policy uncertainty on PM2.5 pollution is greater than the positive effect of economic policy uncertainty on PM2.5 pollution. Therefore, the increase in economic policy uncertainty reduces PM2.5 pollution.

Hypothesis 1b: The increase in economic policy uncertainty reduces corporate investment and increases investment in renewable energy, thereby reducing PM2.5 pollution. However, the increase of economic policy uncertainty will also hinder the innovative behavior of enterprises, which will increase the PM2.5 pollution. Overall, the positive effect of economic policy uncertainty on PM2.5 is greater than the negative effect of economic policy uncertainty on PM2.5 pollution. Therefore, economic policy uncertainty increases PM2.5 pollution.

Furthermore, the impact of economic policy uncertainty on PM2.5 pollution may also be heterogeneous and depends on countries' R\&D input scale. Economic policy uncertainty hinders corporate innovation (Cui et al., 2021; Lou et al., 2022). Innovation, especially green technology innovation, 
Fig. 2 The impact mechanism of economic policy uncertainty on PM2.5 pollution

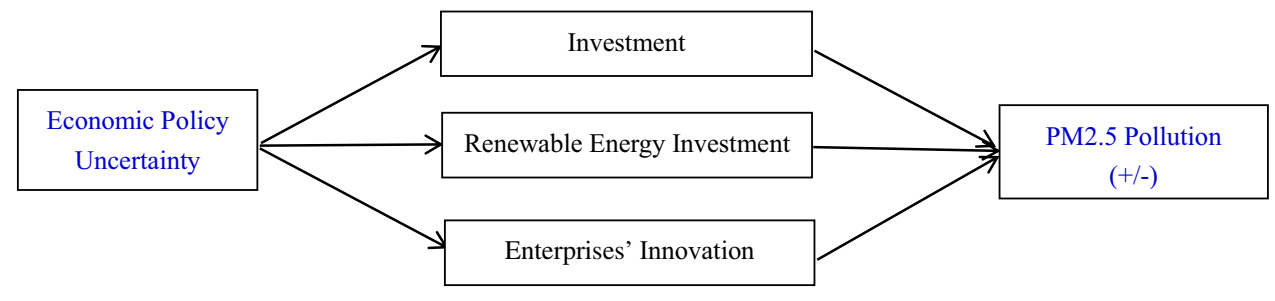

could significantly reduce PM2.5 pollution (Feng et al., 2021; Shan et al., 2021; Chien et al., 2021; Khattak et al., 2022). So, economic policy uncertainty could affect a country's PM2.5 pollution through corporate innovation channel. However, there are large differences in the innovation behavior of countries, which will make the impact of economic policy uncertainty on PM2.5 heterogeneous across countries. Economists have found that economic policy uncertainty has heterogeneous effect on environmental pollution. For example, Pirgaip \& Dinçergök (2020) show that the impact of economic policy uncertainty on $\mathrm{CO} 2$ emissions of G7 countries is very different. Generally, countries with higher R\&D input have strong innovation capabilities. Thus, the increase in economic policy uncertainty has a greater negative impact on the country's corporate innovation activities. That is, increase in economic policy uncertainty can cause a big decline in country's innovation activity. Conversely, countries with lower R\&D input have limited innovation capabilities. The negative effect of economic policy uncertainty on countries $R \& D$ input may be small. Therefore, the impact of increase in economic policy uncertainty on the innovation activities of these countries is relatively weak.

Hence, we propose the following research hypothesis:

Hypothesis 2: The influence of economic policy uncertainty on PM2.5 pollution may be heterogeneous with country's innovation activities.

In summary, economic policy uncertainty affects country's PM2.5 pollution through corporate investment channel and innovation channel, as shown in Fig. 2. In addition, this impact depends on country's R\&D input, so it is heterogeneous in different countries. Next, we will use cross-country unbalanced panel data from 25 countries and panel data fixed effects estimation methods to empirically test the overall impact of economic policy uncertainty on PM2.5 pollution and the heterogeneous impact on different countries.

\section{Empirical strategy}

\section{Empirical model}

In order to empirically test the impact of economic policy uncertainty on PM2.5 pollution, according to Dong et al. (2020) and Pirgaip and Dinçergök (2020), we use the following econometric model:

$\mathrm{PM}_{\mathrm{it}}=\beta_{0}+\beta_{1} \mathrm{EPU}_{\mathrm{it}}+\varphi^{\prime} X_{\mathrm{it}}+\omega_{i}+\mu_{\mathrm{it}}$

In the model, $i$ represents the country and $t$ means year. PM is variable of country's PM2.5 pollution emissions. EPU is variable of economic policy uncertainty, and variable set $X$ includes a series of control variables, including real GDP per capita, square terms of real GDP per capita, financial development, and so on. $\omega_{i}$ is the country fixed effect and $\mu_{\mathrm{it}}$ is the random error term. $\beta_{0}$ and $\beta_{1}$ are the parameters to be estimated. In addition, we use the fixed effects method to estimate the econometric model.

\section{Variables and data}

The dependent variable is PM2.5 pollution emission. The data for the PM2.5 pollution are from the World Bank's World Development Indicators (WDI) database and use mean annual exposure level (micrograms per cubic meter) to measure. For the robustness checks section, we use the population exposed to levels exceeding WHO guideline value ( $\%$ of total) to measure PM2.5 pollution.

For economic policy uncertainty (EPU) variable, there are many ways to measure. We use the data of Baker et al. (2016) to construct the economic policy uncertainty index in the paper. Many economists have used this indicator when analyzing the impact of economic policy uncertainty on the real economy, such as Liu et al. (2020), Sha et al. (2020), and Xu (2020). However, in the Baker et al. (2016)'s research, the economic policy 
Table 1 Definition of variables

\begin{tabular}{|c|c|c|c|}
\hline Variable & Definition & Data source & Literature \\
\hline $\mathrm{PM}$ & $\begin{array}{l}\text { PM2.5 pollution, Mean annual exposure } \\
\text { (micrograms per cubic meter) }\end{array}$ & World bank WDI & Dong et al. (2020) \\
\hline EPU & Economic policy uncertainty & Baker et al., 2016 & Adedoyin and Zakari (2020), Liu et al. (2020), Sha et al. (2020) \\
\hline $\operatorname{lnGDPPC}$ & Logarithm of real GDP per capita & World bank WDI & Ji et al. (2018), Pirgaip and Dinçergök (2020) \\
\hline $\operatorname{lnGDPPC} 2$ & Square of logarithm of real GDP per capita & World bank WDI & Dong et al. (2018), Gao et al. (2019), Ding et al. (2020) \\
\hline FD & $\begin{array}{l}\text { Financial development, domestic credit to } \\
\text { private sector (\% of GDP) }\end{array}$ & World bank WDI & Churchill et al. (2018) \\
\hline Fixed & Gross fixed capital formation (\% of GDP) & World bank WDI & Wang et al. (2018) \\
\hline Trade & Trade value (\% of GDP) & World bank WDI & Du et al. (2018) \\
\hline Pop & Population growth rate (annual \%) & World bank WDI & Wang et al. (2018) \\
\hline Urban & Urban population ( $\%$ of total population) & World bank WDI & Xu and Lin (2018) \\
\hline
\end{tabular}

uncertainty data are monthly data, and all variables such as PM2.5 pollution in this paper are annual data. Therefore, the monthly data of economic policy uncertainty need to be converted into annual data. According to Phan et al. (2020), we take the annual arithmetic average of the monthly data of 12 months each year to calculate the annual economic policy uncertainty data for each country. Currently, the economic policy uncertainty data include only 25 countries in Baker et al. (2016)'s research. ${ }^{1}$ Thus, based on data availability and research needs, the sample used in this paper mainly includes data from 25 countries from 1976 to 2018. These countries include the USA, Australia, Belgium, Brazil, Canada, Chile, China, Colombia, Croatia, France, Germany, Greece, India, Ireland, Italy, Japan, South Korea, Mexico, Netherlands, Pakistan, Russia, Singapore, Spain, Sweden, and UK.

In addition, except economic policy uncertainty, according to Churchill et al. (2018), Pirgaip and Dinçergök (2020), and Dong et al. (2020)'s research, we also control other factors that may affect PM2.5 pollution emissions. These variables are included in the variable set $X$, as follows:

The logarithmic value of real GDP per capita (lnGDPPC), and GDPPC is the real GDP per capita of each country which is calculated by the price of USD in 2020 as the base period.

The square term of lnGDPPC (lnGDPPC2). The reason for controlling the real GDP per capita and its square term is to test the environmental Kuznets effect (Grossman \& Krueger, 1995; Ding et al., 2019). That is: the increase in the level of economic development will deteriorate the environmental quality at the beginning. But after a threshold value, as the level of economic development increases, environmental pollution will decline. Therefore,

$\overline{1}$ http://www.policyuncertainty.com/. the relationship between economic development and environmental pollution may be an inverted U-shaped curve.

Financial development (FD) is measured by the ratio of domestic credit to private sector to GDP.

Fixed is measured by gross fixed capital formation (\% of GDP).

Trade is the ratio of import trade and export trade to GDP. Import and export trade have important impact on PM2.5 pollution emissions, so we also control this variable in the paper.

Pop is population growth rate.

Urban is the urbanization rate, which is expressed by urban population ( $\%$ of total population).

Finally, the definition information of all these variables is shown in Table 1.

\section{Descriptive statistics}

Table 2 is the descriptive statistics of main variables. It can be seen from Table 2 that the maximum value of PM is 97.5994 , the minimum value is 6.1143 , and the average value is 21.2221. The maximum value of EPU is 6.4691,

Table 2 Descriptive statistics

\begin{tabular}{llrrrr}
\hline Variable & Obs & \multicolumn{1}{l}{ Mean } & Std. Dev & \multicolumn{1}{l}{ Min } & \multicolumn{1}{l}{ Max } \\
\hline PM & 261 & 21.2221 & 18.9371 & 6.1143 & 97.5994 \\
EPU & 261 & 1.4120 & 0.8319 & 0.1299 & 6.4691 \\
lnGDPPC & 261 & 9.9548 & 1.0507 & 6.8951 & 10.9572 \\
lnGDPPC2 & 261 & 100.1978 & 19.4577 & 47.5422 & 120.0609 \\
FD & 244 & 122.7842 & 59.8130 & 20.8142 & 278.1189 \\
Fixed & 261 & 22.6815 & 6.1776 & 11.5442 & 45.6899 \\
Trade & 261 & 73.1925 & 62.5699 & 16.6795 & 420.4305 \\
Pop & 261 & 0.7137 & 0.6638 & -1.8537 & 2.4534 \\
Urban & 261 & 77.1845 & 15.8421 & 29.2350 & 100.0000 \\
\hline
\end{tabular}


Table 3 Basic results

\begin{tabular}{|c|c|c|c|c|c|c|c|c|c|}
\hline & Model 1 & Model 2 & Model 3 & Model 4 & Model 5 & Model 6 & Model 7 & Model 8 & Model 9 \\
\hline EPU & $\begin{array}{l}-1.2054 * * * \\
(0.2093)\end{array}$ & $\begin{array}{l}-1.2054 * * \\
(0.4512)\end{array}$ & $\begin{array}{l}-0.9611^{*} \\
(0.5229)\end{array}$ & $\begin{array}{l}-0.8916^{*} \\
(0.4800)\end{array}$ & $\begin{array}{l}-0.9133 * \\
(0.5285)\end{array}$ & $\begin{array}{l}-0.8301 \\
(0.4924)\end{array}$ & $\begin{array}{l}-0.7905^{*} \\
(0.4397)\end{array}$ & $\begin{array}{l}-0.7693^{*} \\
(0.4191)\end{array}$ & $\begin{array}{l}-0.8216^{*} \\
(0.4074)\end{array}$ \\
\hline $\operatorname{lnGDPPC}$ & & & $\begin{array}{l}-2.0809 \\
(1.4056)\end{array}$ & $\begin{array}{l}8.3986 * \\
(4.0216)\end{array}$ & $\begin{array}{l}8.2075 \\
(8.116)\end{array}$ & $\begin{array}{l}4.7732 * * * \\
(1.3081)\end{array}$ & $\begin{array}{l}5.9110^{*} \\
(3.2578)\end{array}$ & $\begin{array}{l}3.6982 \\
(5.5308)\end{array}$ & $\begin{array}{l}9.5423 * * * \\
(2.8040)\end{array}$ \\
\hline $\operatorname{lnGDPPC} 2$ & & & & $\begin{array}{l}-0.5918^{* * * *} \\
(0.1156)\end{array}$ & $\begin{array}{l}-0.5577 \\
(0.4028)\end{array}$ & $\begin{array}{l}-0.3934 * * * \\
(0.0295)\end{array}$ & $\begin{array}{l}-0.4896^{*} \\
(0.2684)\end{array}$ & $\begin{array}{l}-0.3745 \\
(0.3082)\end{array}$ & $\begin{array}{l}-0.6022^{* * * *} \\
(0.1369)\end{array}$ \\
\hline FD & & & & & $\begin{array}{l}-0.0055 \\
(0.0076)\end{array}$ & $\begin{array}{l}-0.0036 \\
(0.0067)\end{array}$ & $\begin{array}{l}-0.0033 \\
(0.0064)\end{array}$ & $\begin{array}{l}-0.0048 \\
(0.0071)\end{array}$ & $\begin{array}{l}0.0044 \\
(0.0072)\end{array}$ \\
\hline Fixed & & & & & & $\begin{array}{l}0.1280 \\
(0.0802)\end{array}$ & $\begin{array}{l}0.1737 * \\
(0.0988)\end{array}$ & $\begin{array}{l}0.2103 \\
(0.1247)\end{array}$ & $\begin{array}{l}0.1892 \\
(0.1277)\end{array}$ \\
\hline Trade & & & & & & & $\begin{array}{l}0.0319 \\
(0.0325)\end{array}$ & $\begin{array}{l}0.0353 \\
(0.0327)\end{array}$ & $\begin{array}{l}0.0407 \\
(0.0332)\end{array}$ \\
\hline Pop & & & & & & & & $\begin{array}{l}0.5595 * \\
(0.3025)\end{array}$ & $\begin{array}{l}-0.6413 \\
(0.5784)\end{array}$ \\
\hline Urban & & & & & & & & & $\begin{array}{l}-0.1721 * * * \\
(0.0230)\end{array}$ \\
\hline Constant & $\begin{array}{l}22.8050 * * * \\
(0.2989)\end{array}$ & $\begin{array}{l}22.8050 * * * \\
(0.5926)\end{array}$ & $\begin{array}{l}43.1989 * * * \\
(13.3448)\end{array}$ & $\begin{array}{l}-1.9173 \\
(38.8588)\end{array}$ & $\begin{array}{l}-2.2122 \\
(40.1256)\end{array}$ & $\begin{array}{l}12.2567 \\
(30.713)\end{array}$ & $\begin{array}{l}7.046 \\
(32.5484)\end{array}$ & $\begin{array}{l}17.0321 \\
(26.3106)\end{array}$ & $\begin{array}{l}-5.0346 \\
(39.7357)\end{array}$ \\
\hline Country FE & Yes & Yes & Yes & Yes & Yes & Yes & Yes & Yes & Yes \\
\hline Obs & 261 & 261 & 261 & 261 & 244 & 244 & 244 & 244 & 244 \\
\hline$R$-squared & 0.1237 & 0.1237 & 0.1548 & 0.1674 & 0.1579 & 0.1772 & 0.1987 & 0.2061 & 0.2215 \\
\hline Number of country & 25 & 25 & 25 & 25 & 25 & 25 & 25 & 25 & 25 \\
\hline
\end{tabular}

Note: Each model in the table is estimated by panel data fixed effects method. Robust standard errors are reported in parenthesis. *, **, and $* * *$ denote statistical significance at the $10 \%, 5 \%$, and $1 \%$ levels, respectively

while the minimum value is 0.1299 , and the average value is 1.4120 . Next, we will empirically test the impact of economic policy uncertainty on PM2.5 pollution emissions.

\section{Results}

\section{Basic results}

Table 3 shows the basic regression results. In Table 3, model 1 only controls the economic policy uncertainty (EPU) variable and uses standard errors. It can be seen that the coefficient of EPU is negative and significant at the $1 \%$ level. This means that the increase in economic policy uncertainty has significantly reduced regional PM2.5 pollution, which is consistent with Anser et al. (2021)'s conclusions. They find that, in the short run, a $1 \%$ increase in world uncertainty index mitigates $\mathrm{CO} 2$ emissions by $0.11 \%$. On the one hand, according to the real option theory, increase in EPU can significantly reduce corporate investment (Gulen and Ion 2015; Drobetz et al., 2018; Liu and Zhang 2019), while decline in investment can reduce regional PM 2.5 emission. Moreover, the increase in EPU can also increase investment in renewable energy (Liu et al., 2020), which will also reduce regional PM2.5 pollution. But on the other hand, the increase in EPU will increase capital costs and inhibit the R\&D investment of enterprises (Xu, 2020), which is not conducive to the green innovation of enterprises, thereby increasing PM2.5 pollution emissions. Therefore, the impact of EPU on PM2.5 pollution depends on the combination effect of these two effects. From the empirical results, the increase in economic policy uncertainty will eventually reduce PM2.5 pollution emissions. This verifies Hypothesis 1a, and Hypothesis $1 \mathrm{~b}$ has not been verified. The negative effect of economic policy uncertainty on PM2.5 pollution is greater than the positive effect of economic policy uncertainty on PM2.5 pollution. Therefore, the increase in economic policy uncertainty reduces PM2.5 pollution. And the results are similar to the conclusion of Adedoyin and Zakari (2020)'s research. In models 2-9 of Table 3, we use robust standard errors. In model 2 , only the variable EPU is controlled, and the coefficient of EPU is still significantly negative. In models 3-9, lnGDPPC, lnGDPPC2, FD, Fixed, Trade, Pop, and Urban variables are added in sequence, and the coefficient of EPU is still significantly negative, except in model 6 . Therefore, 
overall, the increase in EPU significantly reduces PM2.5 air pollution.

Other variables have different impact on PM 2.5 pollution. The result of model 3 shows that the coefficient of lnGDPPC is not significant, which indicates that the impact of economic development on PM2.5 pollution may not be significant. But in model 4, the coefficient of lnGDPPC is positive, which is significant at the $10 \%$ level. Moreover, the coefficient of lnGDPPC 2 is negative and significant at the $1 \%$ level. That is, the increase in economic activities at the beginning deteriorates the environmental quality. However, after a certain threshold is exceeded, as economic scale increases, the service industry in the economy grows rapidly, and new technologies are also used in large quantities. Therefore, the environment quality will be improvement and PM2.5 pollution emissions also decrease. This shows that the relationship between PM2.5 pollution and economic development is an inverted U-shaped curve, which verifies the environmental Kuznets curve, and is consistent with Dong et al. (2018), Du et al. (2018), and Ding et al. (2019)'s research. Although the coefficients of lnGDPPC and $\operatorname{lnGDPPC} 2$ in model 5 and model 8 are not significant, they are also positive and negative values respectively in other models. In addition, in model 6 , model 7 , and model 9, the existence of the environmental Kuznets curve is verified. The impact of financial development and international trade on PM2.5 emissions are not obvious, which can be seen from model 5 , model 6 , model 7 , model 8 , and model 9. The empirical result of model 7 shows that the fixed capital formation increases PM2.5 emissions, which is not conducive to the improvement of environmental quality. This is consistent with the conclusion obtained by Wang et al. (2018). The increase in population growth rate has significantly increased PM2.5 emissions, as shown in model 8. Generally, the increase in population growth rate increases energy consumption, which in turn increases PM2.5 pollution emissions. Finally, the result of model 9 shows that with the increase of urbanization, PM2.5 pollution decreases significantly, which is consistent with the research of Ji et al. (2018) and Xu and Lin (2018). The agglomeration effect and technological progress effect of urbanization will significantly reduce PM2.5 pollution (Dong et al., 2020).

In short, economic policy uncertainty can influence PM2.5 pollution through investment channel and innovation channel. The former channel reduces PM2.5 pollution, while the latter channel increases PM2.5 pollution. Therefore, the impact of EPU on PM2.5 pollution depends on the combination effect of these two channels. From the empirical results, the increase in economic policy uncertainty significantly reduces PM2.5 emissions. The impacts of other variables on PM2.5 pollution are different. There is an inverted U-shaped curve relationship between economic development and PM2.5 pollution. Fixed capital formation and population growth rate increase PM2.5 pollution, while urbanization reduces PM2.5 pollution. The impacts of other variables on PM2.5 pollution are not significant.

\section{Heterogeneous effect}

The increase in economic policy uncertainty has significantly reduced regional PM2.5 pollution emissions through investment channel and innovation channel. However, this effect may be heterogeneous. For example, Pirgaip and Dinçergök (2020) maintain that the impact of economic policy uncertainty on carbon emissions and energy consumption are very different within G7 countries. Dong et al. (2020) find that the impact of urbanization on PM2.5 pollution is also very different in OECD countries, non-OECD countries, and poor countries. Hence, the impact of economic policy uncertainty on PM2.5 pollution is likely to be dependent on countries' $R \& D$ input. Therefore, we reclassify the sample according to countries' R\&D input. Here we use countries' research and development expenditure (\% of GDP) to express R\&D input. And these data are from world bank WDI database. If country's $R \& D$ input is greater than the average value of the R\&D input in the sample, then it is defined as a country with higher R\&D input, and vice versa. Finally, after we classify the sample according to R\&D input, the higher R\&D countries include the USA, Australia, Canada, Germany, UK, France, Belgium, Iceland, Japan, South Korea, Netherlands, Singapore, and Sweden. And there are 12 lower R\&D countries, which are Brazil, Chile, China, Colombia, Croatia, Greece, India, Italy, Mexico, Pakistan, Russia, and Spain. Then, the results are shown in Tables 4 and 5.

\section{Higher R\&D input countries}

First, we conduct empirical tests on samples in which $R \& D$ input is greater than the average value, which are the higher R\&D input countries. The results are shown in Table 4 . Model 1 in Table 4 uses standard errors, while the other 8 models use robust standard errors. It can be seen from model 1 in Table 4 that the coefficient of EPU is -0.6595 , which is significant at the $1 \%$ level. This once again shows that the increase in economic policy uncertainty significantly reduces PM2.5 pollution, and verifies Hypothesis 1a. After re-estimating the model using robust standard errors in model 2, the coefficient of EPU is still significantly negative. Then adding $\operatorname{lnGDPPC}, \ln$ GDPPC $2, \mathrm{FD}$, Fixed, Trade, Pop, and Urban variables in turn, in model 3, model 4, model 8, and model 9, the coefficient of EPU is still significantly negative. In addition, by comparing the results of Tables 3 and 4, it can be seen that the coefficient of EPU in Table 4 is greater than the coefficient of EPU in Table 3. This means that for countries with higher R\&D input, the increase in economic policy uncertainty will 


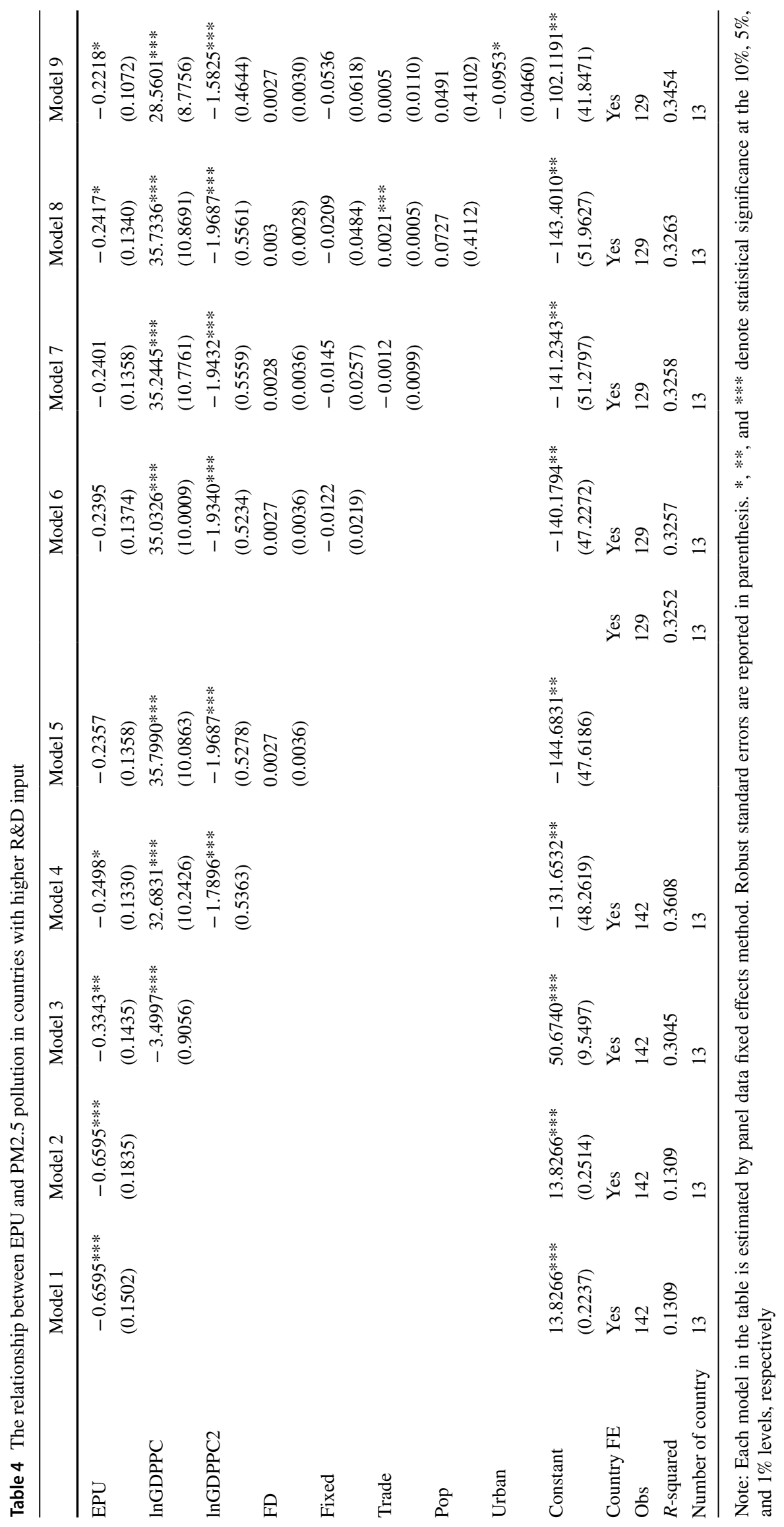


Table 5 The relationship between EPU and PM2.5 pollution in countries with lower R\&D input

\begin{tabular}{|c|c|c|c|c|c|c|c|c|c|}
\hline & Model 1 & Model 2 & Model 3 & Model 4 & Model 5 & Model 6 & Model 7 & Model 8 & Model 9 \\
\hline EPU & $\begin{array}{l}-2.0004 * * * \\
(0.4346)\end{array}$ & $\begin{array}{l}-2.0004 * * \\
(0.7458)\end{array}$ & $\begin{array}{l}-1.8390^{*} \\
(0.9855)\end{array}$ & $\begin{array}{l}-1.7595^{*} \\
(0.8930)\end{array}$ & $\begin{array}{l}-1.3259^{*} \\
(0.7191)\end{array}$ & $\begin{array}{l}-0.8530 * * * \\
(0.2080)\end{array}$ & $\begin{array}{l}-0.9088 \\
(0.7123)\end{array}$ & $\begin{array}{l}-0.8564 * * \\
(0.3396)\end{array}$ & $\begin{array}{l}-0.4116 \\
(0.6339)\end{array}$ \\
\hline $\operatorname{lnGDPPC}$ & & & $\begin{array}{l}-1.0553 \\
(2.1481)\end{array}$ & $\begin{array}{l}22.4417 * * * \\
(7.0445)\end{array}$ & $\begin{array}{l}30.0229 \\
(32.0702)\end{array}$ & $\begin{array}{l}36.3268 \\
(29.3611)\end{array}$ & $\begin{array}{l}33.2244 \\
(26.0643)\end{array}$ & $\begin{array}{l}32.8671 \\
(26.2253)\end{array}$ & $\begin{array}{l}58.2554 * \\
(31.1124)\end{array}$ \\
\hline $\operatorname{lnGDPPC} 2$ & & & & $\begin{array}{l}-1.4192 * * * \\
(0.4881)\end{array}$ & $\begin{array}{l}-1.8068 \\
(1.8009)\end{array}$ & $\begin{array}{l}(2.405 \\
-1.7763)\end{array}$ & $\begin{array}{l}-2.2415 \\
(1.5813)\end{array}$ & $\begin{array}{l}-2.2438 \\
(1.6253)\end{array}$ & $\begin{array}{l}-3.3807^{*} \\
(1.8125)\end{array}$ \\
\hline FD & & & & & $\begin{array}{l}-0.0336^{* * * *} \\
(0.0046)\end{array}$ & $\begin{array}{l}-0.0212 \\
(0.0289)\end{array}$ & $\begin{array}{l}-0.0162 \\
(0.0279)\end{array}$ & $\begin{array}{l}-0.0183 \\
(0.0276)\end{array}$ & $\begin{array}{l}-0.0046 \\
(0.0198)\end{array}$ \\
\hline Fixed & & & & & & $\begin{array}{l}0.4014 * * \\
(0.1798)\end{array}$ & $\begin{array}{l}0.4221 * * \\
(0.1471)\end{array}$ & $\begin{array}{l}0.4632 * * \\
(0.1843)\end{array}$ & $\begin{array}{l}0.4882 * * \\
(0.1739)\end{array}$ \\
\hline Trade & & & & & & & $\begin{array}{l}0.0915 \\
(0.0978)\end{array}$ & $\begin{array}{l}0.0738 \\
(0.1129)\end{array}$ & $\begin{array}{l}0.1122 \\
(0.0952)\end{array}$ \\
\hline Pop & & & & & & & & $\begin{array}{l}-0.6701 \\
(1.1626)\end{array}$ & $\begin{array}{l}-1.0788 \\
(1.1773)\end{array}$ \\
\hline Urban & & & & & & & & & $\begin{array}{l}-0.6373^{*} \\
(0.2898)\end{array}$ \\
\hline Constant & $\begin{array}{l}33.6173 * * * \\
(0.5883)\end{array}$ & $\begin{array}{l}33.6173 * * * \\
(0.9292)\end{array}$ & $\begin{array}{l}43.0387 * * \\
(18.4097)\end{array}$ & $\begin{array}{l}-51.8543 \\
(111.4448)\end{array}$ & $\begin{array}{l}-85.2708 \\
(138.2654)\end{array}$ & $\begin{array}{l}-103.2727 \\
(119.9097)\end{array}$ & $\begin{array}{l}-94.3685 \\
(105.4417)\end{array}$ & $\begin{array}{l}-90.3146 \\
(103.0505)\end{array}$ & $\begin{array}{l}-187.2331 \\
(134.0382)\end{array}$ \\
\hline Country FE & Yes & Yes & Yes & Yes & Yes & Yes & Yes & Yes & Yes \\
\hline Obs & 119 & 119 & 119 & 119 & 115 & 115 & 115 & 115 & 115 \\
\hline$R$-squared & 0.1666 & 0.1666 & 0.1729 & 0.1933 & 0.2195 & 0.2987 & 0.3318 & 0.3344 & 0.379 \\
\hline Number of country & 12 & 12 & 12 & 12 & 12 & 12 & 12 & 12 & 12 \\
\hline
\end{tabular}

Note: Each model in the table is estimated by panel data fixed effects method. Robust standard errors are reported in parenthesis. *, **, and $* * *$ denote statistical significance at the $10 \%, 5 \%$, and $1 \%$ levels, respectively

make the country's innovation activities drop a lot, so this will greatly increase PM2.5 pollution emissions. This will mitigate the negative effect of economic policy uncertainty on PM2.5 pollution through investment channel. Therefore, for higher R\&D input countries, the increase in economic policy uncertainty makes PM2.5 pollution decrease little. Furthermore, it can be seen from Table 4 that there is still an inverted U-shaped curve relationship between PM2.5 pollution and economic development. The coefficient of Trade variable in model 8 is significantly positive. That is, the increase in international trade increases PM2.5 pollution. This means that trade leads to more economic activities, which in turn increases PM2.5 pollution. Model 9 shows that urbanization significantly reduces PM2.5 pollution.

\section{Lower R\&D input countries}

Table 5 reports the empirical results by using sample of countries whose R\&D input is less than the average value. Similarly, model 1 in Table 5 uses standard errors, while other models use robust standard errors. As in model 1, the coefficient of EPU is -2.0004 , which is significant at the $1 \%$ level. That is, the increase of economic policy uncertainty significantly reduces PM2.5 pollution. After adding
lnGDPPC, lnGDPPC2, FD, Fixed, Trade, Trade, Pop, and Urban variables in sequence, except for model 7 and model 9, the coefficients of EPU in models 3-8 are all significantly negative. And the coefficients of economic policy uncertainty in Table 5 are smaller than that of economic policy uncertainty in Table 3. That is, for countries with lower R\&D input, the increase in economic policy uncertainty causes decline in investment, which in turn leads to decline in PM2.5 emissions. However, for countries with relatively lower R\&D input, the increase in economic policy uncertainty leads to a smaller decline in R\&D input, which also leads to a limited increase in PM2.5 pollution. Therefore, overall, for countries with lower levels of $R \& D$ input, increase in economic policy uncertainty will have a greater negative effect on the reduction of PM2.5 pollution.

In short, the effect of economic policy uncertainty on PM2.5 emissions is heterogeneous. That is, for countries with higher R\&D input, the increase in economic policy uncertainty will greatly reduce $R \& D$ investment or innovation, which will increase PM2.5 pollution. Therefore, to a certain extent, the increase in economic policy uncertainty makes the reduction of PM2.5 pollution in countries with higher R\&D input smaller. However, for countries with lower $R \& D$ input, their own $R \& D$ input is relatively small, 
Table 6 Robustness tests with new EPU index

\begin{tabular}{|c|c|c|c|c|c|c|c|c|c|}
\hline & Model 1 & Model 2 & Model 3 & Model 4 & Model 5 & Model 6 & Model 7 & Model 8 & Model 9 \\
\hline EPU2 & $\begin{array}{l}-0.7296 * * * \\
(0.1677)\end{array}$ & $\begin{array}{l}-0.7296^{* * * *} \\
(0.2514)\end{array}$ & $\begin{array}{l}-0.5347 * \\
(0.2974)\end{array}$ & $\begin{array}{l}-0.4924^{*} \\
(0.2739)\end{array}$ & $\begin{array}{l}-0.4865^{*} \\
(0.281)\end{array}$ & $\begin{array}{l}-0.4217 \\
(0.2648)\end{array}$ & $\begin{array}{l}-0.3924 \\
(0.2313)\end{array}$ & $\begin{array}{l}-0.3751^{*} \\
(0.2174)\end{array}$ & $\begin{array}{l}-0.3382 \\
(0.2180)\end{array}$ \\
\hline $\operatorname{lnGDPPC}$ & & & $\begin{array}{l}2.5417 * * \\
(1.1780)\end{array}$ & $\begin{array}{l}9.8442 \\
(8.2792)\end{array}$ & $\begin{array}{l}8.7453 \\
(8.1895)\end{array}$ & $\begin{array}{l}4.9848 \\
(6.2888)\end{array}$ & $\begin{array}{l}7.1320 * \\
(3.7412)\end{array}$ & $\begin{array}{l}3.8060 \\
(5.503)\end{array}$ & $\begin{array}{l}10.5825 \\
(9.3465)\end{array}$ \\
\hline $\operatorname{lnGDPPC} 2$ & & & & $\begin{array}{l}-0.6970 \\
(0.4378)\end{array}$ & $\begin{array}{l}-0.6079 \\
(0.4215)\end{array}$ & $\begin{array}{l}-0.4261 \\
(0.3443)\end{array}$ & $\begin{array}{l}-0.5232 * \\
(0.2872)\end{array}$ & $\begin{array}{l}-0.4019 \\
(0.3175)\end{array}$ & $\begin{array}{l}-0.6628 \\
(0.4659)\end{array}$ \\
\hline FD & & & & & $\begin{array}{l}-0.0062 \\
(0.0084)\end{array}$ & $\begin{array}{l}-0.0042 \\
(0.0073)\end{array}$ & $\begin{array}{l}-0.0038 \\
(0.0070)\end{array}$ & $\begin{array}{l}-0.0055 \\
(0.0078)\end{array}$ & $\begin{array}{l}-0.0048 \\
(0.0078)\end{array}$ \\
\hline Fixed & & & & & & $\begin{array}{l}0.1376 \\
(0.0843)\end{array}$ & $\begin{array}{l}0.1848 * \\
(0.1042)\end{array}$ & $\begin{array}{l}0.223 \\
(0.1323)\end{array}$ & $\begin{array}{l}0.1962 \\
(0.1326)\end{array}$ \\
\hline Trade & & & & & & & $\begin{array}{l}0.0330 \\
(0.0331)\end{array}$ & $\begin{array}{l}0.0364 \\
(0.0335)\end{array}$ & $\begin{array}{l}0.0426 \\
(0.0343)\end{array}$ \\
\hline Pop & & & & & & & & $\begin{array}{l}-0.5836 \\
(0.6065)\end{array}$ & $\begin{array}{l}-0.6733 \\
(0.6130)\end{array}$ \\
\hline Urban & & & & & & & & & $\begin{array}{l}-0.1991 * * * \\
(0.0355)\end{array}$ \\
\hline Constant & $\begin{array}{l}22.2523 * * * \\
(0.2657)\end{array}$ & $\begin{array}{l}22.2523 * * * \\
(0.355)\end{array}$ & $\begin{array}{l}47.2797 * * * \\
(11.3391)\end{array}$ & $\begin{array}{l}-6.2413 \\
(38.4729)\end{array}$ & $\begin{array}{l}-2.9721 \\
(39.1536)\end{array}$ & $\begin{array}{l}12.7752 \\
(29.2426)\end{array}$ & $\begin{array}{l}7.4662 \\
(31.1793)\end{array}$ & $\begin{array}{l}17.9377 \\
(25.0016)\end{array}$ & $\begin{array}{l}-7.8732 \\
(41.3045)\end{array}$ \\
\hline Country FE & Yes & Yes & Yes & Yes & Yes & Yes & Yes & Yes & Yes \\
\hline Obs & 261 & 261 & 261 & 261 & 244 & 244 & 244 & 244 & 244 \\
\hline$R$-squared & 0.0746 & 0.0746 & 0.1234 & 0.1411 & 0.1319 & 0.1543 & 0.1772 & 0.1852 & 0.2063 \\
\hline Number of country & 25 & 25 & 25 & 25 & 25 & 25 & 25 & 25 & 25 \\
\hline
\end{tabular}

Note: Each model in the table is estimated by panel data fixed effects method. Robust standard errors are reported in parenthesis. *, **, and $* * *$ denote statistical significance at the $10 \%, 5 \%$, and $1 \%$ levels, respectively

so increase in economic policy uncertainty will cause more reduction of PM2.5 pollution. Therefore, compared with countries with higher R\&D input, the increase in economic policy uncertainty makes the reduction of PM2.5 pollution in countries with lower R\&D investment greater. This also verifies the Hypothesis 2.

\section{Robustness checks}

In order to verify the robustness of the above empirical results, we use three methods to conduct robustness checks, which are changing the calculation method of EPU, changing the calculation method of PM2.5 index, and estimating the models using 2SLS methods.

First, Baker et al. (2016)'s economic policy uncertainty data are monthly data, and we calculate the annual value of economic policy uncertainty through the annual weighted average method. In order to ensure the reliability of the annual economic policy uncertainty data, according to Demir and Ersan (2017), we use the economic policy uncertainty data in December of each year as the EPU value of the current year. The estimation results are shown in Table 6. It can be seen that in model 1 and model 2, the EPU coefficient is significantly negative. After adding each control variable, the EPU coefficients are significantly negative in model 3, model 4, model 5, and model 8 . Therefore, the results still show that the increase in economic policy uncertainty significantly reduces PM2.5 pollution.

Secondly, we use population exposed to levels exceeding WHO guideline value (\% of total) to calculate PM2.5 pollution emissions, and estimate the models. The results are shown in Table 7. Obviously, in the 9 models of Table 7, the coefficients of EPU are all significantly negative, which again shows that the increase of economic policy uncertainty significantly reduces PM2.5 pollution.

Finally, considering the potential endogenous problem, we use the one-period lagged EPU variable as the instrumental variable, and use the panel data instrumental variable methods to estimate the econometric model. The estimation results are shown in Table 8. In model 1, the coefficient of EPU is significantly negative. After controlling a series of other variables, as shown in the results of models $2-8$, the coefficients of EPU are still significantly negative. In addition, the environmental Kuznets assumption still holds, as shown in model 7. Fixed and Trade variable significantly increase PM2.5 emissions, as shown in model 5, model 6, model 7, and model 8 . The result of model 8 shows that 
Table 7 Robustness tests with new PM2.5 index

\begin{tabular}{|c|c|c|c|c|c|c|c|c|c|}
\hline & Model 1 & Model 2 & Model 3 & Model 4 & Model 5 & Model 6 & Model 7 & Model 8 & Model 9 \\
\hline EPU & $\begin{array}{l}-3.8753 * * * \\
(0.6499)\end{array}$ & $\begin{array}{l}-3.8753 * * * \\
(0.9104)\end{array}$ & $\begin{array}{l}-3.5084 * * * \\
(0.8673)\end{array}$ & $\begin{array}{l}-3.0121^{* * *} \\
(0.9808)\end{array}$ & $\begin{array}{l}-3.3961^{* * *} \\
(1.1107)\end{array}$ & $\begin{array}{l}-3.2330^{* * * *} \\
(1.0572)\end{array}$ & $\begin{array}{l}-3.2551^{* * *} \\
(1.0458)\end{array}$ & $\begin{array}{l}-3.3378^{* * *} \\
(1.0335)\end{array}$ & $\begin{array}{l}-2.9396^{* * *} \\
(1.0371)\end{array}$ \\
\hline $\operatorname{lnGDPPC}$ & & & $\begin{array}{l}-3.1253 \\
(3.8505)\end{array}$ & $\begin{array}{l}71.7252 * * \\
(29.8796)\end{array}$ & $\begin{array}{l}82.1814 * * \\
(36.3547)\end{array}$ & $\begin{array}{l}75.4465^{* *} \\
(35.1676)\end{array}$ & $\begin{array}{l}74.8117 \text { ** } \\
(35.6302)\end{array}$ & $\begin{array}{l}83.4524 * * \\
(39.5895)\end{array}$ & $\begin{array}{l}109.9767^{* *} \\
(46.584)\end{array}$ \\
\hline lnGDPPC2 & & & & $\begin{array}{l}-4.2269^{* *} \\
(1.8304)\end{array}$ & $\begin{array}{l}-5.0064 * * \\
(2.2741)\end{array}$ & $\begin{array}{l}-4.6842 * * \\
(2.2144)\end{array}$ & $\begin{array}{l}-4.6305^{*} \\
(2.2487)\end{array}$ & $\begin{array}{l}-5.0799 * * \\
(2.4461)\end{array}$ & $\begin{array}{l}-6.1135^{* *} \\
(2.5971)\end{array}$ \\
\hline FD & & & & & $\begin{array}{l}0.0403 \\
(0.0285)\end{array}$ & $\begin{array}{l}0.0441 \\
(0.0327)\end{array}$ & $\begin{array}{l}0.0439 \\
(0.0326)\end{array}$ & $\begin{array}{l}0.0500 \\
(0.0351)\end{array}$ & $\begin{array}{l}0.0521 \\
(0.0355)\end{array}$ \\
\hline Fixed & & & & & & $\begin{array}{l}0.2510 \\
(0.2932)\end{array}$ & $\begin{array}{l}0.2254 \\
(0.2896)\end{array}$ & $\begin{array}{l}0.0824 \\
(0.2602)\end{array}$ & $\begin{array}{l}-0.0133 \\
(0.2957)\end{array}$ \\
\hline Trade & & & & & & & $\begin{array}{l}-0.0178 \\
(0.036)\end{array}$ & $\begin{array}{l}-0.0308 \\
(0.0445)\end{array}$ & $\begin{array}{l}-0.0059 \\
(0.052)\end{array}$ \\
\hline Pop & & & & & & & & $\begin{array}{l}2.1847 \\
(1.9995)\end{array}$ & $\begin{array}{l}1.8134 \\
(1.8857)\end{array}$ \\
\hline Urban & & & & & & & & & $\begin{array}{l}-0.7810 \\
(0.5055)\end{array}$ \\
\hline Constant & $\begin{array}{l}82.2022 * * * \\
(0.9279\end{array}$ & $\begin{array}{l}82.2022 * * * \\
(1.1957\end{array}$ & $\begin{array}{l}112.8323^{* * *} \\
(38.4338\end{array}$ & $\begin{array}{l}-209.4131^{*} \\
(115.3398\end{array}$ & $\begin{array}{l}-238.7299^{*} \\
(136.8561\end{array}$ & $\begin{array}{l}-210.3545 \\
(132.8933\end{array}$ & $\begin{array}{l}-207.4473 \\
(135.1133\end{array}$ & $\begin{array}{l}-246.4415 \\
(153.8023\end{array}$ & $\begin{array}{l}-346.5943^{*} \\
(182.6315\end{array}$ \\
\hline Country FE & Yes & Yes & Yes & Yes & Yes & Yes & Yes & Yes & Yes \\
\hline Obs & 261 & 261 & 261 & 261 & 244 & 244 & 244 & 244 & 244 \\
\hline $\mathrm{R}$-squared & 0.1314 & 0.1314 & 0.1386 & 0.2047 & 0.1974 & 0.2053 & 0.2061 & 0.218 & 0.2522 \\
\hline $\begin{array}{c}\text { Number of } \\
\text { country }\end{array}$ & 25 & 25 & 25 & 25 & 25 & 25 & 25 & 25 & 25 \\
\hline
\end{tabular}

Note: Each model in the table is estimated by panel data fixed effects method. Robust standard errors are reported in parenthesis. *, **, and $* * *$ denote statistical significance at the $10 \%, 5 \%$, and $1 \%$ levels, respectively

the agglomeration effect and technological progress effect caused by the increase in urbanization have significantly reduced PM2.5 pollution.

In summary, by changing the calculation methods of economic policy uncertainty and PM2.5 indicators, and selecting appropriate instrumental variable for 2SLS estimation, the empirical results still show that the increase in economic policy uncertainty significantly reduces PM2.5 pollution. Thus, the empirical results of the paper are robust.

\section{Conclusions and policy implications}

Reducing environmental pollution is an important way to promote sustainable economic development. This paper conducts theoretical and empirical study on the impact of economic policy uncertainty on PM2.5 pollution. Economic policy uncertainty has important impact on PM2.5 pollution through investment channel and innovation channel. Specifically, according to real option theory, increase in economic policy uncertainty can reduce investment, thereby reduce PM2.5 pollution. However, increase in economic policy uncertainty can hinder corporate's innovation activities, which in turn make PM2.5 pollution increase. Therefore, the impact of economic policy uncertainty on
PM2.5 pollution depends on the combination effect of these two different effects. Furthermore, using 25 countries' unbalanced panel data and fixed effects estimation methods, we empirically test the impact of economic policy uncertainty on PM2.5 pollution. The results show that, with the increase of economic policy uncertainty, countries' PM2.5 pollution has significantly decreased. In addition, economic policy uncertainty has heterogeneous effect on countries' PM2.5 pollution. Compared with countries that have higher $R \& D$ input, increase in economic policy uncertainty makes the reduction of PM2.5 pollution in countries with relatively lower R\&D input higher. By changing the measurement methods of economic policy uncertainty and PM2.5 pollution indicators, and using 2SLS methods to estimate the models, the conclusions of the paper are robust.

The paper may have some limitations. Firstly, we use country-level data to do the empirical analysis. But there are many differences across countries, for example, development level of manufacturing industry, culture, and political regime, etc. All these factors may influence the PM2.5 pollution. We cannot control all these variables in the empirical models. Secondly, the economic policy uncertainty data are annual data in the paper. But in Baker et al. (2016)'s research, the economic policy uncertainty data are monthly data. So annual data may 
Table 8 2SLS estimation results

\begin{tabular}{|c|c|c|c|c|c|c|c|c|}
\hline & Model 1 & Model 2 & Model 3 & Model 4 & Model 5 & Model 6 & Model 7 & Model 8 \\
\hline EPU & $\begin{array}{l}-1.5085^{* * * *} \\
(0.2774)\end{array}$ & $\begin{array}{l}-1.0279 * * * \\
(0.3086)\end{array}$ & $\begin{array}{l}-1.0214^{* * * *} \\
(0.3136)\end{array}$ & $\begin{array}{l}-1.0762 * * * \\
(0.3629)\end{array}$ & $\begin{array}{l}-0.8974 * * \\
(0.3683)\end{array}$ & $\begin{array}{l}-0.9101^{* *} \\
(0.3654)\end{array}$ & $\begin{array}{l}-0.8848^{* *} \\
(0.3653)\end{array}$ & $\begin{array}{l}-0.7702^{* *} \\
(0.3724)\end{array}$ \\
\hline $\operatorname{lnGDPPC}$ & & $\begin{array}{l}3.6387 * * * \\
(0.8926)\end{array}$ & $\begin{array}{l}-2.8540 \\
(6.5215)\end{array}$ & $\begin{array}{l}-2.9461 \\
(7.3531)\end{array}$ & $\begin{array}{l}5.1326 \\
(7.3285)\end{array}$ & $\begin{array}{l}3.4491 \\
(7.3255)\end{array}$ & $\begin{array}{l}12.4538 * \\
(6.4394)\end{array}$ & $\begin{array}{l}-0.8478 \\
(7.6848)\end{array}$ \\
\hline $\operatorname{lnGDPPC} 2$ & & & $\begin{array}{l}-0.0433 \\
(0.3565)\end{array}$ & $\begin{array}{l}-0.8229 * \\
(0.4107)\end{array}$ & $\begin{array}{l}0.9039 * * \\
(0.4075)\end{array}$ & $\begin{array}{l}-0.0458 \\
(0.4087)\end{array}$ & $\begin{array}{l}-0.9589 * * * \\
(0.3139)\end{array}$ & $\begin{array}{l}-0.1017 \\
(0.4172)\end{array}$ \\
\hline FD & & & & $\begin{array}{l}-0.0054 \\
(0.0061)\end{array}$ & $\begin{array}{l}-0.0037 \\
(0.0060)\end{array}$ & $\begin{array}{l}-0.0033 \\
(0.0060)\end{array}$ & $\begin{array}{l}-0.0048 \\
(0.0061)\end{array}$ & $\begin{array}{l}-0.0047 \\
(0.0060)\end{array}$ \\
\hline Fixed & & & & & $\begin{array}{l}0.1293 * * \\
(0.0576)\end{array}$ & $\begin{array}{l}0.1648 * * * \\
(0.0605)\end{array}$ & $\begin{array}{l}0.2050 * * * \\
(0.0667)\end{array}$ & $\begin{array}{l}0.1773 * * * \\
(0.0670)\end{array}$ \\
\hline Trade & & & & & & $\begin{array}{l}0.0249 * \\
(0.0129)\end{array}$ & $\begin{array}{l}0.0285 * * \\
(0.0131)\end{array}$ & $\begin{array}{l}0.0337 * * \\
(0.0132)\end{array}$ \\
\hline Pop & & & & & & & $\begin{array}{l}0.5589 \\
(0.3876)\end{array}$ & $\begin{array}{l}0.6267 \\
(0.3857)\end{array}$ \\
\hline Urban & & & & & & & & $\begin{array}{l}-0.1697 * * \\
(0.0834)\end{array}$ \\
\hline Constant & $\begin{array}{l}22.8540 * * * \\
(0.3831)\end{array}$ & $\begin{array}{l}58.5609 * * * \\
(8.7038)\end{array}$ & $\begin{array}{l}55.0799 * \\
(29.9599)\end{array}$ & $\begin{array}{l}55.1534 * \\
(33.1475)\end{array}$ & $\begin{array}{l}64.8616^{* * *} \\
(33.0311)\end{array}$ & $\begin{array}{l}56.3863^{*} \\
(33.0502)\end{array}$ & $\begin{array}{l}65.2300 * \\
(33.5485)\end{array}$ & $\begin{array}{l}48.744 \\
(34.0758)\end{array}$ \\
\hline Country FE & Yes & Yes & Yes & Yes & Yes & Yes & Yes & Yes \\
\hline Obs & 257 & 257 & 257 & 240 & 240 & 240 & 240 & 240 \\
\hline$R$-squared & 0.0089 & 0.6749 & 0.6697 & 0.6388 & 0.7529 & 0.7412 & 0.7498 & 0.8260 \\
\hline Number of country & 25 & 25 & 25 & 25 & 25 & 25 & 25 & 25 \\
\hline
\end{tabular}

Note: Each model in the table is estimated by panel data fixed effects method. Robust standard errors are reported in parenthesis. *, **, and $* * *$ denote statistical significance at the $10 \%, 5 \%$, and $1 \%$ levels, respectively

lose some information about economic policy uncertainty. Thirdly, we classify the sample according to countries $R \& D$ input and find that the effect of economic policy uncertainty on PM2.5 pollution is heterogeneous and depends on country's R\&D input scale. However, there may be some other factors which also will cause the heterogeneous effect of economic policy uncertainty on PM2.5 pollution. Finally, we analyze the influence mechanism of economic policy uncertainty on PM2.5 pollution, but lack mathematical model to describe this effect. Thus, for future research, we will do more work in the following aspects. First, we will try to use micro-level data, for example, firm-level data within one country, to empirical test the effect of economic policy uncertainty on environmental pollution. Thus, we may get more interesting empirical results. Second, monthly data may have more information about economic policy uncertainty. For future work, we will try to use monthly economic policy uncertainty data to do the empirical analysis. Furthermore, we may find more factors that could influence the effect of economic policy uncertainty on PM2.5 pollution. Finally, we will construct mathematical models to straightforward analyze the effect on economic policy uncertainty on environmental pollution.
The study has important policy implications. First of all, for the government, while introducing a series of economic policies to promote economic development, it must also be inclined to promote investment in renewable energy. Secondly, government should create a good external and financial environment, increase continuous subsidies for innovation, and promote enterprise innovation, especially green technology innovation. Moreover, continuous subsidies for corporate innovation are also important. This requires the government to support corporate innovation in financing policies and pay attention to the sustainability of subsidies. Finally, government should also increase efforts to promote urbanization, continuously improve the effect of talent agglomeration and technological progress, and provide continuous impetus for the green development of the real economy. In short, increase in economic policy uncertainty can reduce PM2.5 pollution emissions. But this does not mean that the government should frequently introduce a series of economic stimulus policies to improve environmental quality and reduce environmental pollution. Because if the government has introduced too many economic policies, it is not conducive to the innovation activities of enterprises, and it will also deteriorate the environmental quality. For the sustainable development, 
it is essential to increase investment in renewable energy, eliminate outdated production capacity, optimize industrial structure, increase subsidies for innovation and promote urbanization to reduce regional PM2.5 pollution and improve environmental quality.

Author contribution Daleng Xin contributed to write the original draft and do the empirical analysis. Liguo Xin contributed to do the empirical study, review and edit the paper

Funding The authors would like to appreciate the financial support from Natural Science Foundation of Shandong Province (grant number: ZR2020QG027) and Youth Innovation Science and Technology Program of Shandong Province (grant number: 2019RWE015).

Data Availability The data and materials are available from the corresponding author upon reasonable request.

\section{Declarations}

Ethics approval Not applicable.

Consent to participate Not applicable.

Consent for publication All authors have given consent to the publication of this article.

Competing interests The authors declare no competing interests.

\section{References}

Adedoyin FF, Zakari A (2020) Energy consumption, economic expansion, and $\mathrm{CO} 2$ emission in the UK: the role of economic policy uncertainty. Sci Total Environ 738:140014. https://doi.org/10. 1016/j.scitotenv.2020.140014

Ahsan T, Al-GAMRH B, Mirza SS (2021) Economic policy uncertainty and sustainable financial growth: does business strategy matter? Financ Res Lett 102381. https://doi.org/10.1016/j.frl. 2021.102381

Akron S, Demir E, Díez-Esteban JM, García-Gómez CD (2020) Economic policy uncertainty and corporate investment: evidence from the U.S. hospitality industry. Tour Manag 77:104019. https://doi. org/10.1016/j.tourman.2019.104019

Amin A, Dogan E (2021) The role of economic policy uncertainty in the energy-environment nexus for China: evidence from the novel dynamic simulations method. J Environ Manage 292:112865. https://doi.org/10.1016/J.JENVMAN.2021.112865

Anser MK, Apergis N, Syed QR (2021) Impact of economic policy uncertainty on $\mathrm{CO} 2$ emissions: evidence from top ten carbon emitter countries. Environ Sci Pollut Res 28(23):29369-29378. https:// doi.org/10.1007/S11356-021-12782-4

Atanassov J, Julio B, Leng T (2015) The bright side of political uncertainty: the case of R\&D. https://doi.org/10.2139/SSRN.2693605

Baker SR, Bloom N, Davis SJ (2012) Has economic policy uncertainty hampered the recovery. https://doi.org/10.2139/SSRN.2009451

Baker SR, Bloom N, Davis SJ (2016) Measuring economic policy uncertainty. Quart J Econ 131(4):1593-1636. https://doi.org/ 10.2139/SSRN.2198490
Bernanke BS (1983) Irreversibility, uncertainty, and cyclical investment. Quart J Econ 98(1):85-106. https://doi.org/10.2307/ 1885568

Bloom N (2007) The impact of uncertainty shocks. National Bureau of Economic Research

Bloom N, Bond S, van Reenen J (2007) Uncertainty and investment dynamics. Rev Econ Stud 74(2):391-415. https://doi.org/10. 1111/J.1467-937X.2007.00426.X

Bulan LT (2005) Real options, irreversible investment and firm uncertainty: new evidence from U.S. firms. Rev Financ Econ 14(3):255-279. https://doi.org/10.2139/SSRN.293152

Cao X, Kostka G, Xu X (2019) Environmental political business cycles: the case of PM2.5 air pollution in Chinese prefectures. Environ Sci Policy 93:92-100. https://doi.org/10.1016/J. ENVSCI.2018.12.006

Cheng Z, Li L, Liu J (2020) The impact of foreign direct investment on urban PM2.5 pollution in China. J Environ Manag 265:110532. https://doi.org/10.1016/J.JENVMAN.2020.110532

Chien F, Sadiq M, Nawaz MA, Hussain MS, Tran TD, Le Thanh T (2021) A step toward reducing air pollution in top Asian economies: the role of green energy, eco-innovation, and environmental taxes. J Environ Manage 297:113420. https://doi.org/ 10.1016/j.jenvman.2021.113420

Churchill SA, Inekwe J, Ivanovski K, Smyth R (2018) The environmental Kuznets curve in the OECD: 1870-2014. Energy Econ 75:389-399. https://doi.org/10.1016/J.ENECO.2018.09.004

Cohen AJ, Brauer M, Burnett R, Anderson HR, Frostad J, Estep K, Balakrishnan K, Brunekreef B, Dandona L, Dandona R, Feigin V, Freedman G, Hubbell B, Jobling A, Kan H, Knibbs L, Liu Y, Martin R, Morawska L, Forouzanfar MH (2017) Estimates and 25-year trends of the global burden of disease attributable to ambient air pollution: an analysis of data from the Global Burden of Diseases Study 2015. Lancet Glob Health 389(10082):1907-1918

Cui X, Wang C, Liao J, Fang Z, Cheng F (2021) Economic policy uncertainty exposure and corporate innovation investment: evidence from ChinaPac Basin Financ J 67. https://doi.org/10. 1016/J.PACFIN.2021.101533

D'Mello R, Toscano F (2020) Economic policy uncertainty and short-term financing: the case of trade credit. J Corp Finan. https://doi.org/10.1016/J.JCORPFIN.2020.101686

Dejuán D, Ghirelli C (2018) Policy uncertainty and investment in Spain (Issue 48, pp. 1-42). https://doi.org/10.2139/SSRN.33065 60

Demir E, Ersan O (2017) Economic policy uncertainty and cash holdings: Evidence from BRIC countries. Emerg Mark Rev 33:189_ 200. https://doi.org/10.1016/J.EMEMAR.2017.08.001

Ding Y, Zhang M, Chen S, Wang W, Nie R (2019) The environmental Kuznets curve for PM2.5 pollution in Beijing-Tianjin-Hebei region of China: A spatial panel data approach. J Clean Prod 220:984-994. https://doi.org/10.1016/J.JCLEPRO.2019.02.229

Dong K, Sun R, Dong C, Li H, Zeng X, Ni G (2018) Environmental Kuznets curve for PM2.5 emissions in Beijing, China: What role can natural gas consumption play? Ecol Ind 93:591-601. https:// doi.org/10.1016/J.ECOLIND.2018.05.045

Dong Q, Lin Y, Huang J, Chen Z (2020) Has urbanization accelerated PM2.5 emissions? An empirical analysis with cross-country data. China Econ Rev 59:101381. https://doi.org/10.1016/j.chieco. 2019.101381

van Donkelaar A, Martin RV, Brauer M, Boys BL (2014) Use of satellite observations for long-term exposure assessment of global concentrations of fine particulate matter. Environ Health Perspect 123(2):135-143. https://doi.org/10.1289/EHP.1408646

Drobetz W, Ghoul SE, Guedhami O, Janzen M (2018) Policy uncertainty, investment, and the cost of capital. J Financ Stab 39:28-45. https://doi.org/10.1016/J.JFS.2018.08.005 
Du G, Liu S, Lei N, Huang Y (2018) A test of environmental Kuznets curve for haze pollution in China: evidence from the penal data of 27 capital cities. J Clean Prod 205:821-827. https://doi.org/10. 1016/J.JCLEPRO.2018.08.330

Feng Y, Wang X, Liang Z (2021) How does environmental information disclosure affect economic development and haze pollution in Chinese cities? The mediating role of green technology innovation. Sci Total Environ 775:145811. https://doi.org/10.1016/j. scitotenv.2021.145811

Ghosal V, Ye Y (2015) Uncertainty and the employment dynamics of small and large businesses. Small Bus Econ 44(3):529-558. https://doi.org/10.1007/S11187-014-9614-0

Grossman GM, Krueger AB (1995) Economic growth and the environment. Quart J Econ 110(2):353-377. https://doi.org/10.2307/ 2118443

Guan J, Xu H, Huo D, Hua Y, Wang Y (2021a) Economic policy uncertainty and corporate innovation: evidence from ChinaPac Basin Financ J 67. https://doi.org/10.1016/J.PACFIN.2021.101542

Guan Y, Xiao Y, Rong B, Zhang N, Chu C (2021b) Long-term health impacts attributable to PM2.5 and ozone pollution in China's most polluted region during 2015-2020. J Clean Prod 321. https://doi. org/10.1016/J.JCLEPRO.2021.128970

Guiso L, Parigi G (1999) Investment and demand uncertainty. Quart J Econ 114(1):185-227. https://doi.org/10.1162/003355399555981

Gulen H, Ion M (2015) Policy uncertainty and corporate investment. Rev Financ Stud 29(3):523-564. https://doi.org/10.1093/RFS/ HHV050

Jens CE (2017) Political uncertainty and investment: causal evidence from U.S. gubernatorial elections. J Financ Econ 124(3):563-579. https://doi.org/10.1016/J.JFINECO.2016.01.034

Ji X, Yao Y, Long X (2018) What causes PM2.5 pollution? Cross-economy empirical analysis from socioeconomic perspective. Energy Pol 119:458-472. https://doi.org/10.1016/J.ENPOL.2018.04.040

Jiang P, Yang J, Huang C, Liu H (2018) The contribution of socioeconomic factors to PM2.5 pollution in urban China. Environ Pollut 233:977-985. https://doi.org/10.1016/J.ENVPOL.2017.09.090

Jiang X, Kong D, Xiao C (2020) Policy certainty and heterogeneous firm innovation: Evidence from China. China Econ Rev. https:// doi.org/10.1016/J.CHIECO.2020.101500

Jiang Y, Zhou Z, Liu C (2019) Does economic policy uncertainty matter for carbon emission? Evidence from US sector level data. Environ Sci Pollut Res 26(24):24380-24394. https://doi.org/10. 1007/s11356-019-05627-8

Julio B, Yook Y (2012) Political uncertainty and corporate investment cycles. J Financ 67(1):45-83. https://doi.org/10.1111/J.15406261.2011.01707.X

Kang W, Lee K, Ratti RA (2014) Economic policy uncertainty and firm-level investment. J Macroecon 39:42-53. https://doi.org/10. 1016/J.JMACRO.2013.10.006

Khattak SI, Ahmad M, Haq Z, ul, Shaofu, G., \& Hang, J. (2022) On the goals of sustainable production and the conditions of environmental sustainability: does cyclical innovation in green and sustainable technologies determine carbon dioxide emissions in G-7 economies. Sustain Prod Consum 29:406-420. https://doi. org/10.1016/j.spc.2021.10.022

Leahy JV, Whited TM (1996) The effect of uncertainty on investment: Some Stylized Facts. J Money, Credit, Bank 28(1):64-83. https:// doi.org/10.2307/2077967

Leduc S, Liu Z (2012) Uncertainty shocks are aggregate demand shocks. J Monet Econ 82:20-35. https://doi.org/10.1016/J. JMONECO.2016.07.002

Lim SS, Vos T, Flaxman AD, Danaei G, Shibuya K, Adair-Rohani H, AlMazroa MA, Amann M, Anderson HR, Andrews KG, Aryee M, Atkinson C, Bacchus LJ, Bahalim AN, Balakrishnan K, Balmes J, Barker-Collo S, Baxter A, Bell ML, Ezzati M (2012) A comparative risk assessment of burden of disease and injury attributable to 67 risk factors and risk factor clusters in 21 regions, 1990-2010: a systematic analysis for the Global Burden of Disease Study 2010. Lancet 380(9859):2224-2260. https://doi.org/10.1016/S0140-6736(12)61766-8

Liu G, Zhang C (2019) Economic policy uncertainty and firms' investment and financing decisions in China. China Econ Rev. https://doi.org/10.1016/J.CHIECO.2019.02.007

Liu Q, Wang S, Zhang W, Li J, Dong G (2019) The effect of natural and anthropogenic factors on PM2.5: Empirical evidence from Chinese cities with different income levels. Sci Total Environ 653:157-167. https://doi.org/10.1016/J.SCITOTENV.2018.10. 367

Liu R, He L, Liang X, Yang X, Xia Y (2020) Is there any difference in the impact of economic policy uncertainty on the investment of traditional and renewable energy enterprises? - a comparative study based on regulatory effects. J Clean Prod 255. https:// doi.org/10.1016/J.JCLEPRO.2020.120102

Lou Z, Chen S, Yin W, Zhang C, Yu X (2022) Economic policy uncertainty and firm innovation: Evidence from a risk-taking perspective. Int Rev Econ Financ 77:78-96. https://doi.org/10. 1016/J.IREF.2021.09.014

Luo X, Sun K, Li L, Wu S, Yan D, Fu X, Luo H (2021) Impacts of urbanization process on PM2.5 pollution in " $2+26$ " cities. J Clean Prod 284. https://doi.org/10.1016/J.JCLEPRO.2020. 124761

McDonald RL, Siegel D (1986) The value of waiting to invest. Quart J Econ 101(4):707-727. https://doi.org/10.2307/1884175

Mulligan CB (2014) Uncertainty, redistribution, and the labor market since 2007. Iza J Labor Policy 3(1):1-16. https://doi.org/10.1186/ 2193-9004-3-8

Nilavongse R, Rubaszek M, Uddin GS (2020) Economic policy uncertainty shocks, economic activity, and exchange rate adjustments. Econ Lett 186:108765. https://doi.org/10.1016/j.econlet.2019. 108765

Nodari GT (2014) Financial regulation policy uncertainty and credit spreads in the US. J Macroecon 41:122-132. https://doi.org/10. 1016/J.JMACRO.2014.05.006

Pangaribuan M, Chuang KJ, Chuang HC (2019) Association between exposures to air pollution and biomarkers of cardiovascular disease in Northern Taiwan. Atmos Pollut Res 10(4):1250-1259. https://doi.org/10.1016/J.APR.2019.02.008

Phan DHB, Iyke BN, Sharma SS, Affandi Y (2020) Economic policy uncertainty and financial stability-Is there a relation? Econ Model 1-12. https://doi.org/10.1016/J.ECONMOD.2020.02.042

Pindyck RS (1990) Irreversibility, uncertainty, and investment. J Econ Lit 29(3). https://doi.org/10.3386/W3307

Pindyck RS, Solimano A (1993) Economic instability and aggregate investment. NBER Macroecon Annu 8:259-318. https://doi.org/ $10.1086 / 654223$

Pirgaip B, Dinçergök B (2020) Economic policy uncertainty, energy consumption and carbon emissions in G7 countries: evidence from a panel Granger causality analysis. Environ Sci Pollut Res 1-17. https://doi.org/10.1007/S11356-020-08642-2

Romano T, Fumagalli E (2018) Greening the power generation sector : understanding the role of uncertainty. Renew Sustain Energy Rev 91:272-286. https://doi.org/10.1016/J.RSER.2018.03.098

Sha Y, Kang C, Wang Z (2020) Economic policy uncertainty and mergers and acquisitions: Evidence from China. Econ Model 89:590-600. https://doi.org/10.1016/J.ECONMOD.2020.03.029

Shan S, Genç SY, Kamran HW, Dinca G (2021) Role of green technology innovation and renewable energy in carbon neutrality: a sustainable investigation from Turkey. J Environ Manage 294:113004. https://doi.org/10.1016/j.jenvman.2021.113004

Signoretta PE, Buffel V, Bracke P (2019) Mental wellbeing, air pollution and the ecological state. Health Place 57:82-91. https://doi. org/10.1016/J.HEALTHPLACE.2019.03.003 
Stein LCD, Stone EC (2013) The effect of uncertainty on investment, hiring, and R\&D: causal evidence from equity options. https://doi. org/10.2139/SSRN.1649108

Wang N, Zhu H, Guo Y, Peng C (2018) The heterogeneous effect of democracy, political globalization, and urbanization on PM2.5 concentrations in G20 countries: Evidence from panel quantile regression. J Clean Prod 194:54-68. https://doi.org/10.1016/J. JCLEPRO.2018.05.092

Wang Q, Kwan MP, Zhou K, Fan J, Wang Y, Zhan D (2019) The impacts of urbanization on fine particulate matter (PM2.5) concentrations: Empirical evidence from 135 countries worldwide. Environ Pollut 247:989-998. https://doi.org/10.1016/J.ENVPOL. 2019.01.086

Wang Y, Chen CR, Huang YS (2014) Economic policy uncertainty and corporate investment: Evidence from China. Pac Basin Financ J 26:227-243. https://doi.org/10.1016/J.PACFIN.2013.12.008

Wen Q, Zhang T (2022) Economic policy uncertainty and industrial pollution: The role of environmental supervision by local governments. China Econ Rev 71:101723. https://doi.org/10.1016/j. chieco.2021.101723

Wu W, Zhang M, Ding Y (2020) Exploring the effect of economic and environment factors on PM2.5 concentration: a case study of the Beijing-Tianjin-Hebei region. J Environ Manag 268:110703. https://doi.org/10.1016/j.jenvman.2020.110703

Xie X, Ai H, Deng Z (2020) Impacts of the scattered coal consumption on PM2.5 pollution in China. J Clean Prod 245. https://doi.org/10. 1016/J.JCLEPRO.2019.118922

Xin D, Zhang Y (2020) Threshold effect of OFDI on China's provincial environmental pollution. J Clean Prod 258. https://doi.org/10. 1016/J.JCLEPRO.2020.120608

Xu B, Lin B (2018) What cause large regional differences in PM2.5 pollutions in China? Evidence from quantile regression model. J Clean Prod 174:447-461. https://doi.org/10.1016/J.JCLEPRO. 2017.11.008
Xu Z (2020) Economic policy uncertainty, cost of capital, and corporate innovation. J Bank Finance 111(2). https://doi.org/10.1016/J. JBANKFIN.2019.105698

Yan D, Kong Y, Jiang P, Huang R, Ye B (2021) How do socioeconomic factors influence urban PM2.5 pollution in China? Empirical analysis from the perspective of spatiotemporal disequilibrium. Sci Total Environ 761:143266. https://doi.org/10.1016/J.SCITO TENV.2020.143266

Yang J, Zhang B (2018) Air pollution and healthcare expenditure: Implication for the benefit of air pollution control in China. Environ Int 120:443-455. https://doi.org/10.1016/J.ENVINT.2018. 08.011

Yu J, Shi X, Guo D, Yang L (2021) Economic policy uncertainty (EPU) and firm carbon emissions: evidence using a China provincial EPU index. Energy Economics 94. https://doi.org/10.1016/J. ENECO.2020.105071

Zhang M, Sun X, Wang W (2020) Study on the effect of environmental regulations and industrial structure on haze pollution in China from the dual perspective of independence and linkage. J Clean Prod 256. https://doi.org/10.1016/J.JCLEPRO.2020.120748

Zhang Y, Chen X, Mao Y, Shuai C, Jiao L, Wu Y (2021) Analysis of resource allocation and PM2.5 pollution control efficiency: evidence from 112 Chinese cities. Ecol Indic, 127. https://doi.org/ 10.1016/J.ECOLIND.2021.107705

Zou Q, Shi J (2020) The heterogeneous effect of socioeconomic driving factors on PM2.5 in China's 30 province-level administrative regions: Evidence from Bayesian hierarchical spatial quantile regression. Environ Pollut 264. https://doi.org/10.1016/J. ENVPOL.2020.114690

Publisher's note Springer Nature remains neutral with regard to jurisdictional claims in published maps and institutional affiliations. 